\title{
Keterampilan Sosial Siswa pada Pembelajaran Kooperatif Quiz-Quiz Trade dan Peer Assessment di Sekolah Dasar
}

\author{
Ridha Afriani Fitri ${ }^{1}$, Fattah Hanurawan ${ }^{2}$, Lia Yuliati ${ }^{3}$ \\ ${ }^{1}$ Pendidikan Dasar-Universitas Negeri Malang \\ ${ }^{2}$ Psikologi-Universitas Negeri Malang \\ ${ }^{3}$ Pendidikan Fisika-Universitas Negeri Malang
}

\section{INFO ARTIKEL}

\section{Riwayat Artikel:}

Diterima: 13-03-2019

Disetujui: 10-09-2019

\section{Kata kunci:}

quiz-quiz trade; peer assessment; social skills; primary school; keterampilan sosial; sekolah dasar

\section{ABSTRAK}

\begin{abstract}
This study aims to examine the effect of cooperative learning models QuizQuiz Trade and peer assessment to social skill student. This study used quasiexperimental design with pretest-posttest control group design that measured by a skill questionnaire with a Likert scale and analyzed using anacova test. The result showed the quiz-quiz trade learning model and peer assessment were able to develop student's social skills. The anacova test showed the significance value $0.00<0.05$, so that model quizquiz trade and peer assessment could be improved students' social skills.
\end{abstract}

\begin{abstract}
Abstrak: Penelitian ini bertujuan untuk mengetahui keterampilan sosial siswa dnegan menggunakan model pembelajaran quiz-quiz trade dan peer assessment. Penelitian ini menggunakan quasi eksperimen dengan desain penelitian Pretest-Posttest Control Group Design dengan analisis menggunakan uji Anacova. Instrumen menggunakan angket keterampilan dengan skala likert. Temuan dari penelitian ini mengungkapkan bahwa model pembelajaran quiz-quiz trade dan peer assessment mampu mengembangkan keterampilan sosial siswa. Data hasil uji anacova menyatakan bahwa nilai signifikansi adalah $0,00<0,05$ sehingga diambil kesimpulan bahwa ada pengaruh model quiz-quiz trade dan peer assessment dalam meningkatkan keterampilan sosial siswa.
\end{abstract}

\author{
Alamat Korespondensi: \\ Ridha Afriani Fitri \\ Pendidikan Dasar \\ Universitas Negeri Malang \\ Jalan Semarang 5 Malang \\ E-mail: ridharaf10@gmail.com
}

Pendidikan memiliki peran penting dalam membentuk manusia yang berkualitas sehingga terciptalah manusia yang dapat bersaing di era modern. Jenjang pendidikan yang memiliki peran dalam membentuk manusia yang berkualitas yaitu sekolah dasar. Saat siswa berada di sekolah dasar mereka akan dibekali dengan pemahaman, kemampuan dan keterampilan dasar yang akan mereka butuhkan baik di lingkungan akademik maupun non akademik. Seiring dengan kemajuan zaman dan semakin tingginya jenjang pendidikan, siswa akan dihadapkan dengan kondisi dan keadaan yang berbeda pada saat pendidikan sebelumnya. Perubahan kondisi ini dapat berupa orang baru, aturan yang baru serta lingkungan fisik yang baru. Dengan perubahan-perubahan ini, siswa sebaiknya dibekali dengan keterampilan serta kemampuan yang mampu membuat siswa menyesuaikan dirinya, salah satu bekal tersebut adalah keterampilan sosial.

(Bierman \& Welsh, 2010) mengemukakan bahwa keterampilan sosial merupakan sesuatu yang mencerminkan kapasitas peserta didik untuk mengintegrasikan kognitif, afektif, dan perilaku dalam beradaptasi secara fleksibel menjadi beragam situasi dan tuntutan sosial. Hal ini didukung oleh pendapat (Takahashi, Okada, Hoshino, \& Anme, 2015) mengemukakan bahwa kecakapan sosial menjadi pengakuan individu menurut sosial, belajar sikap-sikap yang mengharuskan individu dapat berhubungan secara baik dengan orang lain dan mencegah tanggapan sosial yang ditolak. Interaksi sosial yang terjadi disekitar siswa, baik antara individu dan individu maupun dengan lingkungannya. Dengan adanya interaksi sosial di sekitar siswa dapat dikatakan proses belajar bagi siswa itu sendiri. Dalam berinteraksi dengan lingkungan dan menjalin hubungan sosial dengan orang lain membutuhkan kemampuan berketerampilan sosial (Samanci, 2010). Pada kehidupan sehari-hari kempuan keterampilan sosia dapat dilihat saat seseorang menyelesaikan masalah, hubungan dalam kelompok dan bagaimana mengembangkan potensi diri.

(Lane, Wehby, \& Cooley, 2006) untuk mencapai keberhasilan akademik dan keberhasilan sikap, guru mengakui bahwa keterampilan sosial, perilaku, kerjasama, pengendalian diri, dan tanggung jawab sangat penting untuk diperhatikan. Dengan adanya keterampilan sosial, siswa mampu bekerja sama secara kooperatif dengan orang lain. Siswa akan mudah diterima di lingkungan sosialnya apabila memiliki keterampilan sosial yang baik. Hal ini disebabkan adanya penerimaan oleh teman sebaya, lingkungan dan hubungan dengan orang sekitar dapat terjaga. Hasil penelitian yang dilakukan oleh (Elliott, 2001) mengungkapkan bahwa keterampilan sosial penting bagi fungsi sosial dan kesuksesan akademik siswa serta berperan penting dalam menghindari 
respon negatif dari orang lain. Selain itu, dengan keterampilan sosial yang baik dinilai mampu menyelesaikan masalah secara baik, memiliki kemampuan akademik yang baik dan menumbuhkan minat yang besar di sekolah. Hal senada dikemukakan oleh (Hanurawan \& Soetjipto, 2018) siswa yang mempunyai kemampuan sosial yang baik mampu lebih mudah diterima secara sosial di lingkungan.

Namun, saat ini kenyataannya di kalangan siswa keterampilan sosial dinilai belum tersosialisasi dan berkembang dengan baik. Berdasarkan hasil observasi di SD Negeri Bareng 3 Malang menunjukkan bahwa pembelajaran masih didominasi oleh guru, yang mana guru sepenuhnya masih sebagai narasumber sehingga siswa hanya mencatat, mendengarkan, dan mengerjakan tugas yang ada pada papan tulis maupun buku. Dengan kondisi seperti ini mengakibatkan kurang berkembangnya keterampilan siswa yang mana tidak adanya interaksi antara sesama siswa. Kebanyakan siswa takut untuk menjawab pertanyaan dari guru atau takut bertanya mengenai sesuatu yang belum mereka pahami. Selain itu, ditemui bahwa siswa sudah membuat kelompok kecil dan siswa kesulitan untuk berinteraksi dengan kelompok lain.

Untuk menciptakan proses belajar mengajar yang aktif maka perlu dilakukannya pemilihan metode atau model pembelajaran yang tepat. Model pembelajaran kooperatif quiz-quiz trade merupakan salah satu solusi dalam menyelesaikan masalah ini. (Kagan \& Kagan, 2014) mengemukakan bahwa bahwa model pembelajaran kooperatif Quiz-Quiz Trade ini menekankan pada membangun kelas, keterampilan sosial, keterampilan berkomunikasi, membangun pengetahuan, kemampuan prosedur, memproses informasi dan keterampilan berpikir. Melalui pembelajaran kooperatif, siswa dapat belajar secara berpasangan maupun berkelompok dengan teman sebayanya. Dimana dengan pembelajaran kooperatif siswa akan saling berinteraksi, bertukar pikiran dan ide sehingga menjadikan siswa aktif selama proses pembelajaran. Menurut (Hanurawan \& Soetjipto, 2018) mengemukakan bahwa salah satu pendekatan yang berorientasi pada siswa dan bersifat aktif adalah dengan pembelajaran kooperatif.

Dengan adanya perubahan pembelajaran yang berpusat pada siswa, turut membawa konsekuensi siswa perlu diberi kesempatan terlibat dalam penilaian (Sutrisno, 2012). Jenis penilaian yang ikut mencipatakan siswa yang aktif yaitu peer assessment. (Topping, 2009) mengemukakan bahwa peer assessment adalah penilaian siswa untuk mempertimbangkan dan menetapkan tingkatan, nilai atau kualitas dari sebuah produk atau penampilan teman sebaya. Penilaian ini memungkinkan untuk berhubungan timbal balik, bertatap muka ataupun sebaliknya, dan bergantian menilai antara penilai dengan yang diniliai. LutzeMann dan Ross (Alzaid, 2017) yang mengemukakan bahwa peer assessment juga dapat mengembangkan keterampilan sosial siswa seperti pada pembelajaran kooperatif. Interaksi degan teman sebaya membawa pengaruh besar terhadap kemampuan sosial siswa. Hal ini disebabkan oleh dengan berinteraksi dengan teman sebaya memberikan siswa standar perilaku yang disetujui oleh kelompok sosialnya. Dengan saling berinteraksi dengan orang dewasa maupun teman sebaya dapat membangun dan membentuk ide-ide baru dan mengembangkan wawasan intelektual siswa (Slavin, 2005).

Model kooperatif quiz-quiz trade adalah suatu model pembelajaran yang mana siswa saling bekerja secara berpasangan dan saling memberikan pertanyaan dan jawaban dari pasangan mereka berikan kemudian bergantian peran dan mengucapkan terimakasih (Kagan \& Kagan, 2014). Dengan pembelajaran ini siswa saling berbagi informasi, mengembangkan pengetahuan, saling mengajarkan antar sesama, dan menerima masukan atau respon sehingga diharapkan materi yang dipelajari lebih banyak diserap oleh siswa. Peer assessment yaitu sebuah penilaian yang mana siswa diminta dapat mempertimbangkan dan menetapkan tujuan, nilai atau kualitas dari sebuah produk, atau penampilan temannya. Penilaian ini memungkinkan untuk hubungan timbal balik, bertatap muka maupun sebalikya, dan bergantian menilai antara penilai dengan yang dinilai (Topping, 2009). Pada penilaian ini, penilaian dilakukan siswa dengan teman sebayanya secara berpasangan. Pada penilaian ini terdapat dua nilai, yaitu dari guru (administrator) dan siswa yang menilai pasangannya tersebut (Chang, dkk 2012).

Dalam hal ini model pembelajaran kooperatif Quiz-Quiz Trade dan peer assessment merupakan pembelajaran yang berisikan mengenai siswa yang berkelompok secara berpasangan guna menekankan kepada siswa untuk dapat saling bertukar informasi, mengembangkan pengetahuan dan mengajarkan sesuatu kepada orang lain sehingga siswa diharapkan lebih banyak menyerap materi dengan menggunakan penilaian yang melibatkan para siswa secara langsung dalam proses penilaian untuk memberikan feedback kepada temannya sehingga terjalin sebuah interaksi sosial.

\section{METODE}

Rancangan yang digunakan yakni penelitian kuantitatif menggunakan desain kuasi eksperimental (quasi experiment) tipe Pretest-Posttest Nonequivalent Control Group Design. Populasi penelitian adalah seluruh siswa kelas IV SD Negeri Bareng 3 Malang tahun ajaran 2018/2019 yang berjumlah tiga kelas, sedangkan sampel yang digunakan dalam penelitian ini adalah siswa kelas IVB dan IVC. Pengambilan sampel menggunakan teknik purposive sampling. Instrumen yang digunakan dalam penelitian ini adalah angket keterampilan sosial. Angket pada penelitian ini merupakan angket tertutup dengan menggunakan skala Likert. Dikatakan demikian karena responden tinggal menentukan salah satu jawaban yang sesuai dengan memberikan tanda checklist $(\sqrt{ })$. Aspek keterampilan sosial dalam penelitian ini menggunakan aspek keterampilan sosial yang dikembangkan oleh Gresham dan (Elliott, 2001). 
Sebelum angket disebarkan kepada responden, terlebih dahulu dilakukan uji coba guna mengetahui validitas dan reliabilitas angket. Dari uji coba yang dilakukan, jumlah butir yang direncanakan digunakan sebanyak 80 butir soal, setelah dilakukan uji validitas hasilnya 59 butir soal valid dan dapat dipergunakan untuk penelitian dan memperoleh koefisien reliabilitas sebesar 0,883 dengan tingkat reliabilitas yang sangat tinggi. Analisis data menggunakan teknik analisis statistik deskriptif menggunakan SPSS 20 for windows. Sebelum dilakukan uji hipotesis maka dilakukan uji prasyarat dengan uji normalitas dan uji homogenitas. Uji normalitas dilakukan untuk melihat apakah sampel yang didapat berasal dari populasi yang berdistribusi normal atau tidak, dan digunakan rumus Kolmogrov-Smirnov. Uji homogenitas menggunakan Test of Homogenety of Variances. Setelah diketahui skor tes siswa berdistribusi normal dan mempunyai variansi homogen, maka akan dilakukan uji hipotesis dengan uji anacova.

\section{HASIL}

Pemberian pretest dan postest dilakukan guna untuk mengetahui peningkatan keterampilan sosial siswa Hasil analisis pretest dan posttest kelas kontrol dan kelas eksperimen menunjukkan terdapat perbedaan yang signifikan. Berdasarkan hasil pengelolaan data, maka hasil penelitian ini dapat dijelaskan pada tabel 1. Keterampilan sosial antara kelas eksperimen dan kelas kontrol setelah diberi perlakukan dapat dilihat dari hasil pretest dan postest. Skor rata-rata keterampilan sosial siswa pada hasil pretest dan posttest dapat dilihat pada gambar 1.

Tabel 1. Data Pretest dan Postest Kelas Kontrol dan Kelas Eksperimen

\begin{tabular}{lcccc}
\hline & $\begin{array}{c}\text { Pretest Kelompok } \\
\text { Eksperimen }\end{array}$ & $\begin{array}{c}\text { Postest Kelompok } \\
\text { Eksperimen }\end{array}$ & $\begin{array}{c}\text { Postest Kelompok } \\
\text { Kontrol }\end{array}$ & $\begin{array}{c}\text { Postest Kelompok } \\
\text { Kontrol }\end{array}$ \\
\hline $\mathrm{N}$ & 27 & 27 & 27 & 27 \\
Mean & 62,40 & 79,50 & 65,41 & 75,19 \\
Std Deviasi & 18,96 & 10,50 & 14,57 & 13,50 \\
Minimum & 118 & 165 & 118 & 150 \\
Maksimum & 180 & 208 & 187 & 201 \\
\hline
\end{tabular}

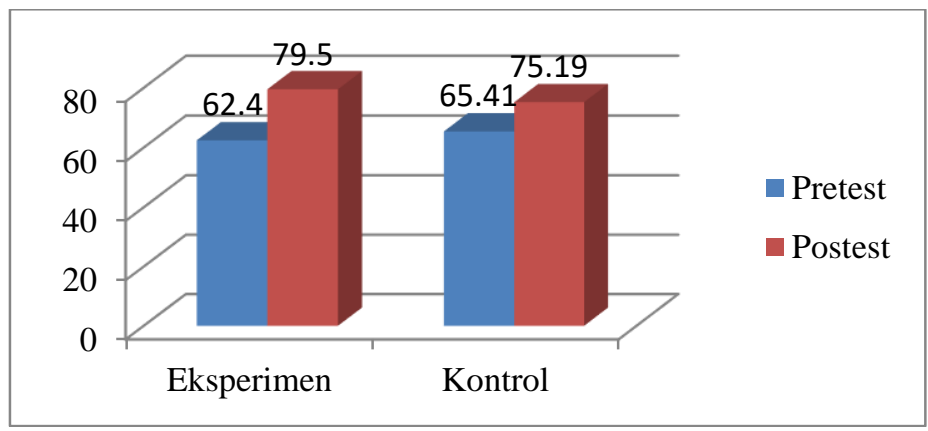

\section{Gambar 1. Skor Rata-Rata Keterampilan Sosial Siswa Kelas Eksperimen dan Kontrol}

Berdasarkan grafik pada gambar 1 menunjukkan bahwa peningkatan skor rata-rata antara kelas eksperimen lebih tinggi dari pada peningkatan pada kelas kontrol. Peningkatan skor pada kelas eksperimen sebanyak 17,1 bila dibandingkan dengan peningkatan kelas kontrol yaitu 9,78.

Tabel 2. Distribusi Frekuensi Nilai Pretest Posttest Keterampilan Sosial Kelas Eksperimen

\begin{tabular}{|c|c|c|c|c|c|c|c|c|c|c|}
\hline \multirow{3}{*}{ No } & \multirow{3}{*}{ Nilai Rata-rata } & \multicolumn{4}{|c|}{ Kelas Eksperimen } & \multicolumn{4}{|c|}{ Kelas Kontrol } & \multirow{3}{*}{ Kategori } \\
\hline & & \multicolumn{2}{|c|}{ Pretest } & \multicolumn{2}{|c|}{ Postest } & \multicolumn{2}{|c|}{ Pretest } & \multicolumn{2}{|c|}{ Postest } & \\
\hline & & $\mathbf{F}$ & $\%$ & $\mathbf{f}$ & $\%$ & f & $\%$ & $\mathbf{F}$ & $\%$ & \\
\hline 1 & $76-100 \%$ & 1 & 3,70 & 22 & 81,48 & 2 & 7,41 & 12 & 44,44 & Tinggi \\
\hline 2 & $51-75 \%$ & 23 & 85,19 & 5 & 18,52 & 24 & 88,89 & 15 & 55,56 & Sedang \\
\hline 3 & $26-50 \%$ & 0 & 0,00 & 0 & 0,00 & 0 & 0,00 & 0 & 0,00 & Rendah \\
\hline 4 & $0-25 \%$ & 3 & 11,11 & 0 & 0,00 & 1 & 3,70 & 0 & 0,00 & Sangat Rendah \\
\hline
\end{tabular}




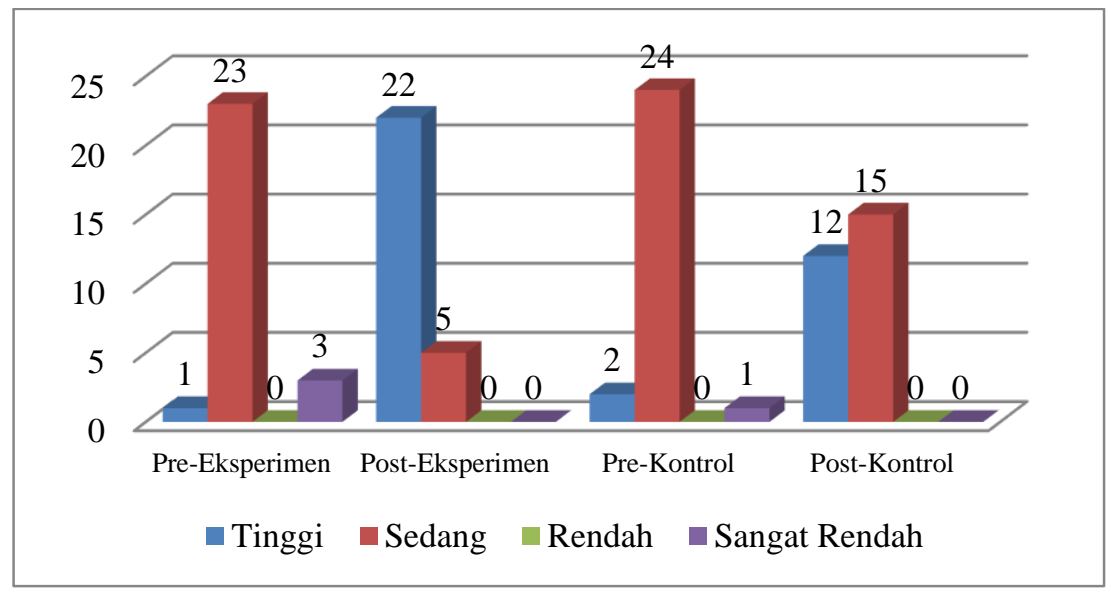

\section{Gambar 2. Distribusi Frekuensi Nilai Pretest dan Postest Keterampilan Sosial Kelas Eksperimen dan Kelas Kontrol}

Dilihat dari grafik pada gambar 2 bahwa terdapat empat tingkat kategori keterampilan sosial yang dicapai oleh siswa yaitu kategori Tinggi, Sedang, Rendah, Sangat Rendah. Pada kategori Rendah tidak terdapat siswa pada kategori ini. Pada pretest kelas eksperimen jumlah siswa paling banyak mencapai kategori Sedang sebanyak 23 siswa dan pada skor postest diperoleh jumlah siswa paling banyak pada kategori Tinggi. Ini menunjukkan terjadi peningkatan keterampilan sosial siswa yang awalnya berada pada kategori sedang meningkat menjadi kategori tinggi.

Secara terperinci, tingkat keterampilan sosial siswa berdasarkan lima bidang keterampilan sosial, yaitu kerjasama, ketegasan, tanggung jawab, empati, dan pengendalian diri dapat dilihat pada tabel 3 beserta skor ketercapaian masing-masing bidang tersebut, baik skor pretest maupun skor postest.

Tabel 3. Skor Pretest dan Postest Keterampilan Sosial Siswa Kelas Eksperimen dan Kontrol

\begin{tabular}{clcccc}
\hline \multirow{2}{*}{ No } & \multirow{2}{*}{ Keterampilan Sosial } & \multicolumn{2}{c}{ Eksperimen } & \multicolumn{2}{c}{ Kontrol } \\
\cline { 3 - 6 } & & Pretest & Postest & Pretest & Postest \\
\hline 1 & Kerjasama & 68,10 & 88,40 & 72,30 & 82,50 \\
2 & Ketegasan & 63,27 & 80,91 & 67,64 & 75,09 \\
3 & Tanggung Jawab & 68,00 & 87,77 & 71,92 & 83,38 \\
4 & Empati & 68,77 & 87,46 & 70,38 & 83,23 \\
5 & Pengendalian Diri & 68,42 & 84,42 & 70,92 & 81,17 \\
\hline
\end{tabular}

Dari tabel 3 menunjukkan terdapat lima aspek keterampilan keterampilan sosial, yaitu kerjasama, ketegasan, tanggung jawab, empati, dan pengendalian diri. Pada kelima aspek ini, aspek ketegasan memperoleh skor paling rendah bila dibandingkan dengan aspek-aspek yang lain. Hal ini dapat dilihat pada pretest dan postest kelas eksperimen maupun kelas kontrol. Aspek yang memperoleh skor paling tinggi pada keterampilan sosial siswa yaitu aspek kerjasama.

Uji hipotesis dilakukan dengan menggunakan uji anacova. Sebelum dilakukan uji anacoba, dilakukan terlebih dahulu uji prasyarat analisis yaitu uji normalitas dan homogenitas keterampilan sosial siswa. Uji normalitas menggunakan uji Kolmogorov Smirnov, yang mana data dikatakan normal apabila nilai signifikansi lebih besar dari 0,05 . Dari tabel di atas menunjukkan bahwa data pretest dan postest baik yang kelas eksperimen maupun kelas kontrol memiliki data yang normal. Dapat dilihat pada tabel 3 nilai signifikansi keterampilan sosial pretest kelas eksperimen sebesar 0,200 dan posttest sebesar 0,147 . Nilai signifikansi pada kedua tes lebih besar dari nilai $\alpha=0,05$ sehingga dapat disimpulkan bahwa data terdistribusi normal. Pada kelas kontrol nilai signifikansi keterampilan sosial pretest sebesar 0,170 dan posttest sebesar 0,200. Data yang diperoleh telah terdistribusi normal karena nilai signifikansi pada kedua tes lebih besar dari nilai $\alpha=0,05$

Uji homogenitas menggunakan bahwa Test of Homogenety of Variances. Data dikatakan homogen apabila nilai signifikansi lebih besar dari 0,05. Dari tabel 4 dapat dilihat bahwa data pretest dan postest memiliki nilai signifikansi yang lebih besar dari 0,05 yang mana pada data pretest signifikansi sebesar 0,076 dan data postest sebesar 0,216. Maka dapat disimpulkan dari kedua hasil uji homogenitas terhadap data keterampilan sosial bersumber dari variansi yang sama atau tidak jauh berbeda keragamannya. 
Hipotesis penelitian ini adalah ada pengaruh model pembelajaran kooperatif quiz-quiz trade dan peer assessment terhadap keterampilan sosial siswa. Berdasarkan perhitungan dengan menggunakan uji anacova diperoleh nilai signifikansi hasil pengujian sebesar $0,000<0,05$, maka sesuai dengan dasar pengambilan keputusan dalam uji Anacova yang sudah dilakukan, maka dapat disimpulkan hipotesis diterima. Hal ini mengindikasikan terdapat pengaruh yang signifikan penerapan model pembelajaran Quiz-Quiz Trade berbantuan peer assessment terhadap keterampilan sosial siswa.

\section{PEMBAHASAN}

Berdasarkan hasil analisis data menggunakan uji anacova didapati keterangan bahwa terdapat pengaruh yang signifikan antara kelompok eksperimen yang diberi treatment model quiz-quiz trade dan peer assessment dengan kelompok kontrol yang tidak diberi perlakuan terhaap keterampilan sosial siswa SD Negeri Bareng 3 Malang. Dengan ini berarti kemampuan sosial siswa mempunyai kemampuan sosial yang lebih tinggi setelah diberikan perlakuan.

Melalui model kooperatif quiz-quiz trade dan peer assessment yang selama proses pembelajaran yang melibatkan siswa dan menuntut siswa untuk aktif sehingga dapat membagun keterampilan sosial siswa itu sendiri. Hal ini didukung dengan pendapat Lutze-Mann dan Ross (Alzaid, 2017) bahwa peer assessment dan pembelajaran kooperatif dapat mengembangkan keterampilan sosial siswa. Hasil penelitian yang mendukung yaitu (Divaharan \& Atputhasamy, 2002) menjelaskan bahwa kemampuan kognitif dan mengembangkan keterampilan sosial dapat melalui peer assessment dan pembelajaran kooperatif yang memotivasi siswa belajar lebih giat dan mendorong siswa menjadi bertanggung jawab. Melalui model pembelajaran quiz-quiz trade dan peer assessment ini siswa belajar secara berpasangan yang mana siswa ditekankan untuk saling berbagi informasi, mengembangkan pengetahuan dan memberikan saran, masukan serta feedback terhadap temannya.

Pembelajaran dengan menggunakan model Quiz-Quiz Trade berbantuan peer assessment memberikan peluang kepada siswa untuk dapat terlibat atif dalam proses pembelajaran. Siswa diajarkan untuk belajar berkelompok, saling berinteraksi dan memberikan umpan balik serta berbagi pengetahuan dan informasi. Melalui pembelajaran ini siswa saling berinteraksi dengan teman sebaya, yang mana teman sebaya merupakan lingkungan sosial pertama bagi siswa untuk belajar untuk beradaptasi dan menjadikannya dasar dalam menjalin hubungan yang lebih luas. Menurut Vygotsky (Slavin, 2005) melalui teman sebaya atau orang dewasa, siwa mampu berinteraksi sosial yang mana ini akan mampu membantu siswa membentuk ide-ide baru dan membangun pengetahuan intelektual mereka.

Pembelajara kooperatif dan peer assessment mampu mengembangkan keterampilan sosial siswa dengan saling berbagi informasi, saling memberikan feedback, saling berinteraksi, berkomunikasi, bekerja sama, dan bertanggung jawab baik dengan guru maupun teman sebaya. Interaksi siswa dengan teman sebaya mampu mengembangkan keterampilan sosial siswa, ini dikarenakan oleh selama proses berinteraksi dan berhubungan siswa akan mulai belajar mempertimbangkan pandangan orang sekitar dan penerimaan dari teman sebayanya. Feedback maupun respons yang diberikan oleh teman sebaya terhadap perilaku siswa tersebut baik berupa penguatan positif maupun negatif menjadi hal yang akan diperhatikan oleh siswa dalam menjalin komunikasi dan interaksi sosial.

(Purchase, 2000) menjelaskan bahwa melalui pembelajaran kooperatif dengan peer assessment diharapkan mampu membuat siswa lebih serius selama proses pembelajaran serta membangun dan mengembangkan kepercayaan antar siswa. Selama berinteraksi dengan pembelajaran kooperatif quiz-quiz trade dan peer assessment siswa mampu menjalin komunikasi, belajar bertanggung jawab baik untuk pribadi dan kelompoknnya, bekerja sama dan membangun kemampuan kompetensi siswa.

Siswa yang mempunyai keterampilan sosial yang baik dapat lebih mudah diterima oleh lingkungan sosialnya, ini disebabkan oleh kemampuan untuk diterima oleh teman sabaya, masyarakat, dapat menjalin persahabatan dan menjaga hubungan yang kuat dengan sekitarnya. Keterampilan sosial yang tinggi juga membantu siswa untuk menyelesaikan masalah secara baik, mengembangkan minat dan mempunyai kemampuan akademik yang baik. Hal ini sejalan dengan pendapat (Hertinjung, 2008) mengemukakan bahwa siswa yang memiliki keterampilan sosial yang baik akan lebih berani mengekspresikan diri, lebih percaya diri dan mudah dalam bergaul dan dapat diterima oleh teman sebaya serta lebih mampu dalam bidang akademik.

\section{SIMPULAN}

Dari data hasil penelitian serta pembahasan pada bab sebelumnya, peneliti menarik kesimpulan bahwa kelompok eksperimen dengan diberi perlakuan dengan model pembelajaran quiz-quiz trade dan peer assessment lebih baik dibandingkan kelompok kontrol tanpa diberikan treatment terhadap mengembangkan keterampilan sosial siswa. Dari uji hipotesis terdapat ada pengaruh model quiz-quiz trade dan peer assessment dalam mengembangkan keterampilan sosial siswa.

Berdasarkan kesimpulan di atas, maka disarankan untuk (1) sekolah dapat memberikan masukkan mengenai penggunaan model kooperatif quiz-quiz trade dan peer assessment untuk digunakan dalam proses belajar mengajar, (2) guru dapat mempertimbangkan untuk menggunakan model kooperatif quiz-quiz trade dan peer assessment untuk meningkatkan kualitas pembelajaran, dan (3) guru dapat menyesuaikan penggunaan model dengan materi, jumlah siswa, alokasi waktu dan tingkat perkembangan siswa. 


\section{DAFTAR RUJUKAN}

Alzaid, J. M. (2017). The Effect of Peer Assessment on the Evaluation Process of Students. International Education Studies, 10(6), 159. https://doi.org/10.5539/ies.v10n6p159

Bierman, K. L., \& Welsh, J. A. (2010). Assessing Social Dysfunction : The Contributions of Laboratory and PerformanceBased Measures. (January 2014), 37-41. https://doi.org/10.1207/S15374424JCCP2904

Chang, S. H., Wu, T. C., Kuo, Y. K., \& You, L. C. (2012). Project-Based Learning with an Online Peer Assessment System in a Photonics Instruction for Enhancing LED Design Skills. Turkish Online Journal of Educational Technology, 11(4), 236246.

Divaharan, S., \& Atputhasamy, L. (2002). An Attempt to Enhance the Quality of Cooperative Learning Through Peer Assessment. Journal of Educational Enquiry, 3(2), 72-83.

Elliott, S. (2001). New Directions in Social Skills Assessment and Intervention for Elementary and Middle School Students. Exceptionality, 9(1), 19-32. https://doi.org/10.1207/s15327035ex091\&2_3

Hanurawan, F., \& Soetjipto, B. E. (2018). Pengembangan Buku Panduan Guru untuk Pembelajaran PKn SD/MI melalui Berbagai Model Cooperative Learning. Jurnal Sains Psikologi, 1(2), 1-14.

Hertinjung, W. S. (2008). Keterampilan Sosial Anak Pra Sekolah Ditinjau dari Interaksi Guru-Siswa Model Mediated Learning Experience Social. Jurnal Penelitian Humaniora, 9(1), 179-191.

Kagan, S., \& Kagan, M. (2014). Kagan Structures, Processing, and Excellence in College Teaching. Journal on Excellence in College Teaching, 25.

Lane, K. L., Wehby, J. H., \& Cooley, C. (2006). Teacher Expectations of Students Classroom Behavior Across the Grade Span: Which Social Skills Are Necessary for Success? Exceptional Children, 72(2), 153-167.

Purchase, H. C. (2000). Learning about Interface Design Through Peer Assessment. Assessment and Evaluation in Higher Education, 25(4), 341-352. https://doi.org/10.1080/026029300449245

Samanci, O. (2010). Teacher View on Social Skills Development in Primary Scholl Students. Education, $131(1), 147-157$.

Slavin, R. E. (2005). Cooperative Learning Theory, Research and Practice. Bandung: Nusa Media.

Sutrisno. (2012). Pembelajaran Fluida Menggunakan Model Jigsaw dengan Peer Assessment untuk Meningkatkan Aktivitas, Sikap Ilmiah, dan Prestasi Belajar Siswa Kelas XI IPA. Journal of Innovative Science Education, 1(1), 10-18.

Takahashi, Y., Okada, K., Hoshino, T., \& Anme, T. (2015). Developmental Trajectories of Social Skills During Early Childhood and Links to Parenting Practices in a Japanese Sample. PLoS ONE, 10(8), 1-14. https://doi.org/10.1371/journal.pone.0135357

Topping, K. J. (2009). Peer Assessment. Theory into Practice, 48(1), 20-27. https://doi.org/10.1080/00405840802577569 